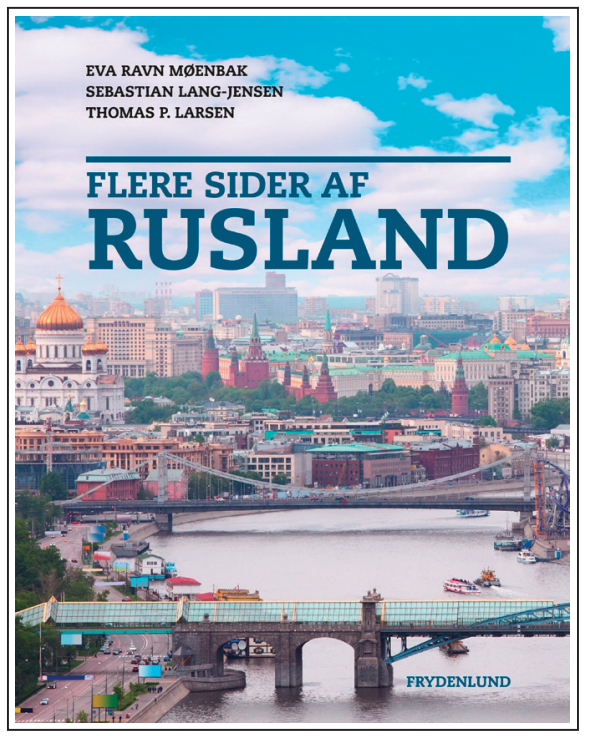

\title{
Flere sider af Rusland
}

Eva Ravn Møenbak, Sebastian Lang-Jensen \& Thomas P. Larsen

Fredriksberg: Frydenlund 2020

112 sider. ISBN 9788772162867

Omtalt av Astrid Bjønness [cand. philol. med russisk hovedfag, Astrid.bjonness@ outlook.com]

Når man har holdt på med Russland i en mannsalder, lest mange hyllemeter om landet og oppholdt seg der i flere omganger, er man ganske oppdatert både på nåtid og fortid. Det skal derfor mye til for å ta for seg nok en gjennomgang av russisk historie og samtid. Ikke desto mindre er Eva Ravn Møenbak, Sebastian Lang-Jensen og Thomas P. Larsens nye lærebok Flere sider af Rusland en bok både for eksperter og nybegynnere. Her får man en oversikt og en repetisjon av - nettopp - flere sider av Russland.

Historiedelen, som utgjør nesten halve boken, er velskrevet, oversiktlig og - ikke minst - opplysende, der vanskelige ord forklares på en forbilledlig måte slik at også studenter som er nye i faget kan forstå hver epoke og alle begrepene man fort kan gå seg vill i. Helt fra Nestorkrøniken og frem til våre dager er overganger, reformer, tsarer og teorier forklart slik at nye russlandsstudenter kan henge med i alle svingene i dette landets innfløkte historie. Utviklingen fra Kievriket og frem til den siste tsar er rettlinjet og nøye beskrevet.

Den kompliserte tiden før revolusjonen er også forklart på en måte de fleste kan forstå. Overgangen og «Stormen på Vinterpalasset» står også ganske klart for oss. Stalin-tiden, med tvangskollektiviseringen og Den store fedrelandskrigen, er rask og dyster lesning - slik det også må være. Sovjets fall og tiden etter blir forklart ved hjelp av mange politiske begreper og sammenligninger med land vi kjenner godt. Ikke minst er begrepet «rettsstat» tema for diskusjon. 
Den neste delen handler om samfunnsutviklingen. Det er komplisert å bestemme hva slags samfunn Russland er. Her er det mange sammenligninger med andre land, diskusjon av begreper som kapitalisme, liberalisme og kommunisme slik at også de som ikke nødvendigvis er så godt politisk skolert begynner å skjønne hvilke grunnleggende forskjeller det er på Russland og Vesten, hvor de har nærmet seg hverandre og hvordan de har skilt lag. Vi får her et godt grunnlag for å forstå forskjellene i tankesett mellom Russland og Vesten. Begreper som «zapadniker» (vestvendte) og «slavofiler» (de som vil holde på de russiske verdier og tradisjoner) blir tydeligere for oss, og presenteres som noe som er gjennomgående i russisk tankesett. Det gir oss bakgrunn for å forstå mange aktuelle problemsstillinger i dagens Russland.

Økonomi er selvsagt også et stort tema her. At det gikk svært dårlig i Sovjet de siste årene før glasnost og perestrojka er ingen hemmelighet, og noen av oss fikk merke det på kroppen da vi oppholdt oss i landet akkurat i de årene. Planøkonomi og markedsøkonomi blir behørig behandlet, og mangelsamfunnet stiger opp i minnet i form av køer og tomme butikkhyller. At økonomien etter andre verdenskrig var i så sterk utvikling i Sovjet sammenlignet med i Vesten, er imidlertid kanskje noe som ikke er like kjent.

Den siste delen av boken handler om religion. Dette er kanskje det tema som er mest ukjent for mange iVesten. Religion spiller en mindre rolle for mange iVesten, og vi er svært uvant med å tenke på religion som et grunnleggende tema i vårt samfunn. Ikke minst er vi uvant med å tenke i symboler og ritualer på samme måte som i den ortodokse kirke. Her går forfatterne langt tilbake og tar med seg en kirkehistorisk oversikt som er helt nødvendig for å forstå den store forskjellen mellom østkirken og vestkirken. Vi blir satt inn i hvordan de to kirkene gikk hver sin vei, og da må man inn i teologiske begreper og ideer. Sammenligningen munner ut i en beskrivelse av den lutherske og den ortodokse kirke. Det er tydeligere forskjeller mellom disse to enn mellom den katolske og den ortodokse.

Forfatterne beskriver "den sanselige» ortodokse kirke der lukten av vokslys og fargene i ikonene, korsangen, kirkerommet og ritualene med korsing, kyssing og bønn gjør det til en storm av alle sanser der skjønnheten står i førersetet. Dette var jo noe av hovedgrunnen til at Vladimir av Kiev lot seg døpe på anbefaling av sine utsendte som hadde falt for det de så i Hagia Sofia i Konstantinopel på slutten av 900-tallet. Som det står i Nestorkrøniken: det var så vakkert at «de visste ikke om de var i himmel eller på jord». Slik fikk skjønnheten herske i Russland. At $71 \%$ av den russiske befolkning i dag betrakter seg som ortodokse kristne er bemerkelsesverdig og viser at religionen har en viktig og fremtredende stilling i landet. Det giør at vi ikke kommer utenom religionens stilling når vi skal prøve å forstå Russland og russerne.

Alt i alt er dette en svært god gjennomgang av Russlands historie og kultur som kan anbefales både for eksperter og nybegynnere. 